Jahangirnagar University J. Biol. Sci. 7(1): 55-64, 2018 (June)

\title{
Evaluation of some integrated management approaches against flower thrips and pod borers of mungbean (Vigna radiata $\mathbf{L}$.)
}

\author{
Md. Altaf Hossain*, M. A. Sarker ${ }^{1}$ and M. G. Azam \\ Pulses Research Centre, Bangladesh Agricultural Research Institute, Ishurdi, Pabna-6620, \\ Bangladesh
}

\begin{abstract}
Efficacy and profitability of different management packages comprising white sticky trap, biopesticide and synthetic insecticides were evaluated against flower thrips and pod borers of mungbean at Pulses Research Center, Ishurdi, Pabna, Bangladesh during two consecutive seasons of kharif-1, 2015 \& 2016. All the treatments significantly reduced flower infestation by thrips and pod borer infestation. The highest percentage of flower infestation and thrips population reduction was observed in installing white sticky trap + spraying of chlorfenapyr (Intrepid $10 \mathrm{SC}$ ) + spraying with emamectin benzoate (Proclaim $5 \mathrm{SG}$ ) followed by farmers practice, i.e. spraying imidacloprid (Imitaf $20 \mathrm{SL}$ ). Again, the highest pod borer infestation reduction was found in installing white sticky trap + spraying azadirachtin (Bio-neem plus $1 \mathrm{EC})+$ spraying with spinosad (Success $2.5 \mathrm{SC}$ ) treated plots followed by installing white sticky trap + spraying chlorfenapyr (Intrepid $10 \mathrm{SC}$ ) + spraying with emamectin benzoate (Proclaim 5 SG). The highest grain yield was obtained from installing white sticky trap + spraying chlorfenapyr (Intrepid 10 SC) + spraying with emamectin benzoate (Proclaim 5 SG), but the highest return came from farmers practice (spraying Imidacloprid). This might be due to the higher cost of Intrepid 10 SC and Proclaim 5 SG reduced the return as well as benefit. Therefore, considering the efficacy and benefit, it is seen that the evaluated IPM package could not be profitable against low level infestation of flower thrips and pod borer infestation. It could be profitable that areas where serious out break of flower thrips and pod borer occurs.
\end{abstract}

Key words: Mungbean, flower thrips, pod borers, integrated management approaches and yield.

\section{INTRODUCTION}

Mungbean (Vigna radiata L.) is one of the important pulse crops in Bangladesh. Due to availability of short duration varieties, farmers are becoming more interested in cultivating this valuable crop after harvesting rabi crops in kharif-I season. However, insect pests usually cause significant loss of this crop yield. More than twelve species of insect pests were found to infest mungbean in Bangladesh (Rahman et al., 2000). Among them, flower thrips and pod borers are the most important. Flower thrips (viz. Megalurothrips distalis Karny, Megalurothrips usitatus Bagnall and Caliothrips indicus Bagnall) are associated mostly with the damage of tender buds and flowers of mungbean. Severe infestation of thrips resulted flower shedding causing significant yield loss (Chhabra \& Kooner, 1985; Lal, 1985). Pod borer is another insect pest causing significant yield reduction. The pod borer, Maruca vitrata damages flowers, flower buds and

\footnotetext{
${ }^{1}$ Bangladesh Agricultural Research Institute, Joydebpur, Gazipur-1701, Bangladesh

* Corresponding author. E-mail: hossain.draltaf@gmail.com
} 
developing or mature pods (Poehlman, 1991). In Bangladesh, pod borers (viz. Maruca vitrata, Helicoverpa armigera Hubner and Euchrysops sp.) often cause serious problem resulting severe loss of the crop (Bakr, 1998). Farmers usually do not take any measure to control the insect pests due to its low profit margin. However, recent development of high yielding and short duration varieties and increased market value of mungbean, farmers become interested on the cultivation of mungbean following pest management measures. Due to easy availability of insecticides, farmers generally take action to control mungbean pests by applying synthetic chemical insecticides. However, some bio-rational tools and bio-pesticides are available to manage insect pests which are safer than synthetic insecticides.

Therefore, it is needed to develop bio-rational based integrated management approach to control mungbean pests specially flower thrips and pod borer and save the crop from significant yield loss. Keeping this in view, attempts have been made to evaluate the efficacy of some IPM package and its economics to manage flower thrips and pod borers.

\section{MATERIALS AND METHODS}

The experiment was conducted at Pulses Research Center, Ishurdi, Pabna, Bangladesh during two consecutive seasons of kharif-I in the years $2015 \& 2016$. There were four treatments viz. $T_{1}, T_{2}$ and $T_{3}$ in the integrated program. The treatments were: $T_{1}=I P M$ Package 1: Installing white sticky trap + two sprays of azadirachtin (Bio-neem plus 1EC) @ $1 \mathrm{ml} / 1$ water first at $100 \%$ flowering stage and second at $100 \%$ podding stage after 7 days + third spraying with spinosad (Success $2.5 \mathrm{SC}$ ) @ $1.25 \mathrm{ml} / \mathrm{l}$ of water at seed developing stage (7 days after second spray), $\mathrm{T}_{2}=$ IPM Package 2: Installing white sticky trap + two sprays of chlorfenapyr (Intrepid 10 SC) @ 1 ml/l water first at 100\% flowering stage and second at $100 \%$ podding stage after 7 days + third spraying with emamectin benzoate (Proclaim 5 SG) @ 1g/l of water at seed developing stage (7 days after second spray), $\mathrm{T}_{3}=$ Farmers' practice: Three spraying of imidacloprid (Imitaf $20 \mathrm{SL}$ ) @ 0.5ml/1 of water at 7 days interval starting from $100 \%$ flowering stage and $\mathrm{T}_{4}=$ Untreated control (Water spray only)

The experiment was laid out in randomized complete block design (RCBD) with four replications. The treatments were randomly allotted in each block. The unit plot size was $4.5 \mathrm{~m} \mathrm{x} 4 \mathrm{~m}$ with a distance of $1.5 \mathrm{~m}$ between the plots and $1.5 \mathrm{~m}$ between the replications. The seeds of BARI Mung- 6 were sown on 24 March in rows with the spacing of $30 \mathrm{~cm}$ in both the years. The unit plot contained 15 rows $\mathrm{x} 4 \mathrm{~m}$. The plant populations were maintained constant by keeping plant to plant distance $7 \mathrm{~cm}$. Urea, triple super phosphate, muriate of potash and boron fertilizers were applied @ 40-90-40-7.5 kg/ha during final land. Two hand weedings were done 12 and 24 days after sowing respectively.

White sticky trap was installed (one trap/plot) at flower bud initiation stage and kept it in the field upto harvest. Three sprayings were done, first at $100 \%$ flowering stage (35 DAS), second at $100 \%$ podding (42 DAS) and third at seed developing stage (49 DAS). 
The population data for thrips in flowers were collected before spraying and one day after spraying. Thrips population was assessed from 20 opened flowers which were randomly collected from two rows of each side of the plot avoiding border and central four rows. The collected flowers were immediately opened on the white paper board and counted the adult and immature thrips present in the flowers. Central nine rows were kept undisturbed for recording data on grain yield.

At maturity, all pods were collected from 10 randomly selected plants from the central four rows of each plot and examined. The infested (bored) and total numbers of pods were counted and the per cent pod infestation was calculated.

The pods of central nine rows of each plot comprising $10.8 \mathrm{~m}^{2}(4 \mathrm{~m} \times 2.7 \mathrm{~m})$ area were harvested. The pods were then threshed; grains were cleaned and sun dried. The grains obtained from each plot were converted into $\mathrm{kg} / \mathrm{ha}$.

The experimental data were analyzed by MSTAT-C software. The per cent infestation data were transformed into square root for statistical analysis. Mean comparisons for treatment parameters were compared by following F-test and Duncan's Multiple Range Test at $5 \%$ level of significance.

The marginal benefit cost ratio (MBCR) was calculated on the basis of prevailing market prices of mungbean, cost of white sticky trap and cost of insecticidal spraying. Marginal benefit cost ratio was calculated as follows:

Marginal BCR $=\frac{\text { Benefit over control }}{\text { Cost of treatment }}$

\section{RESULTS AND DISCUSSION}

Effect of IPM package on flower infestation and thrips population: All IPM package reduced flower infestation and thrips population (Table 1 \& 2). During kharif-I, 2015 (Table 1), it was seen that after one day of spray application, the lowest number of infested flower (4.75/30 open flowers) was observed in the installing of white sticky trap (WST) + Chlorfenapyr sprayed plots which was statistically identical to farmers practiced plot (spraying Imidachloprid). More than 70\% flower infestation reduction was observed in WST + Chlorfenapyr sprayed plots. Accordingly the lowest number of thrips (5.50/30 open flowers) was observed in WST + Chlorfenapyr sprayed plots which was also statistically at par with farmers practice. More than $78 \%$ thrips population was reduced by installing WST with spraying chlorfenapyr. Installation of WST + spraying Azadiractin showed very little effect on the reduction of flower infestation and thrips population which was statistically similar to the untreated control (water spray).

In kharif-I, 2016 (Table 2), after one day of spray application, the lowest number of thrips infested flower (3.38/30 open flowers) was observed in installing of white sticky trap 
(WST) + Chlorfenapyr sprayed plots which was statistically identical to farmers practiced plot (spraying Imidacloprid). About $70 \%$ flower infestation reduction was observed in WST + Chlorfenapyr sprayed plots. Accordingly the lowest number of thrips (3.88/30 open flowers) was observed in WST + Chlorfenapyr sprayed plots which was also statistically at par with farmers practice (spraying Imidachloprid). More than 73\% thrips population was reduced by installing WST + spraying Chlorfenapyr. Installation of WST + spraying Azadiractin also showed significant effect on the reduction of flower infestation and thrips population. These findings are agreed with the findings of Hossain et al. (2015) who reported very good efficacy of Chlorfenapyr (Intrepid 10 SC) for the control of thrips (Thrips tabaci) in onion. Again, Hossain et al. (2011), Hossain (2014), Hossain (2015a) and also Hossain (2015b) found the excellent results of Imidachloprid (Imitaf $20 \mathrm{SL}$ ) in reducing flower infestation and suppression of thrips population in mungbean flowers.

Effects of IPM packages on the incidence of pod borer and grain yield of mungbean: Pod borer infestation varied significantly depending on the efficacy of the IPM packages. During kharif-I 2015, pod infestation varied from 5.25 to $15.50 \%$ (Table 3). The lowest pod borer infestation $(5.25 \%)$ was observed in WST + Azadiractin + Spinosad treated plots followed by WST + Chlorfenapyr + Emamectin Benzoate and also farmers practice. Untreated control plots received the highest $(15.50 \%)$ pod infestation by pod borer. Reduction of pod borer infestation by IPM treatments ranged from 22.58 to $66.13 \%$. The highest pod infestation reduction $(66.13 \%)$ was found in WST + Azadiractin + Spinosad treated plots followed by WST + Chlorfenapyr + Emamectin Benzoate and farmers practiced plots.

In kharif-I 2016, pod infestation varied from 2.13 to $6.75 \%$ (Table 3). The lowest pod borer infestation $(2.13 \%)$ was observed in WST + Azadiractin + Spinosad treated plots followed by WST + Chlorfenapyr + Emamectin Benzoate and also farmers practice. Untreated control plots received the highest $(6.75 \%)$ pod infestation by pod borer. Reduction of pod borer infestation by IPM treatments ranged from 24.00 to $68.44 \%$. The highest pod infestation reduction $(68.44 \%)$ was found in WST + Azadiractin + Spinosad treated plots followed by WST + Chlorfenapyr + Emamectin Benzoate and farmers practice. Sarkar et al. (2015) reported the best effect of spinosad (Success 2.5 SC) in controlling pod borer of mungbean.

Yield: Grain yield of mungbean varied significantly with the level of flower thrips and pod borer infestation depending on the efficacy of the IPM packages (Table 3). During kharif-I 2015, yield varied 1232 to $1378 \mathrm{~kg} / \mathrm{ha}$. The highest grain yield $(1378 \mathrm{~kg} / \mathrm{ha})$ was obtained from WST + Chlorfenapyr + Emamectin Benzoate sprayed plots which was at par with farmers practice followed by WST + Azadiractin + Spinosad treated plots. The lowest yield was recorded from untreated control plots.

In kharif-I 2016, yield varied from 1396 to $1536 \mathrm{~kg} /$ ha. The highest grain yield (1536 $\mathrm{kg} / \mathrm{ha}$ ) was obtained from WST + Chlorfenapyr + Emamectin Benzoate sprayed plots which was at par with WST + Azadiractin + Spinosad treated plots and farmers practice. 
The lowest yield (1396 kg/ha) was recorded from untreated control plots. Due to low level infestation of thrips and pod borer, yield increase over untreated control was very less and it ranged from 7.63 to $11.85 \%$ in kharif-I 2015 and from 6.38 to $10.03 \%$ in kharif-I 2016, respectively.

Return and marginal benefit cost ratio (MBCR): Return and marginal benefit cost ratios are presented in Table 4. The net return and marginal benefit cost ratio varied depending on the efficacy and cost of insecticidal application. During kharif-I 2015 and 2016, the highest net return (Tk. 2125/ha and 1075/ha) and benefit (MBCR 0.60 and 0.32 ), respectively was recorded from farmers practiced plots (i.e., Imidachloprid sprayed plot), although the highest grain yield (1378 kg/ha and $1536 \mathrm{~kg} / \mathrm{ha}$, respectively) was obtained from installation of WST + Chlorfenapyr + Emamectin Benzoate sprayed plots. Due to higher cost of Chlorfenapyr (Intrepid $10 \mathrm{SC}$ ) and Emamectin Benzoate (Proclaim 5 SG) the profit margin of this package goes down and showed very less MBCR. Again due to very less efficacy of Azadiractin (Bio-neem plus 1EC) against flower thrips and also higher cost of both Bio-neem plus $1 \mathrm{EC}$ and Spinosad (Success 2.5 $\mathrm{SC})$, this package also incurred loss.

From this study it is seen that spraying of Chlorfenapyr (Intrepid 10 SC) @ $1 \mathrm{ml} / \mathrm{l}$ and Imidacloprid (Imitaf $20 \mathrm{SL}$ ) @ $0.5 \mathrm{ml} / 1$ showed equally the best efficacy in reducing flower infestation and thrips population. Spraying of Azadirachtin (Bio-neem plus 1EC) showed less efficacy in reducing flower infestation and thrips population compared to Chlorfenapyr and Imidachloprid. Spraying of Spinosad (Success 2.5 SC) @ $1.25 \mathrm{ml} / 1$ showed best efficacy in reducing pod borer infestation followed by Emamectin Benzoate (Proclaim 5 SG).

Therefore, considering overall efficacy and benefit of the evaluated IPM package it could be concluded that farmer's practice, i.e. spraying of Imidacloprid (Imitaf 20 SL @ 0.5 $\mathrm{ml} / \mathrm{l}$ ) was found profitable in low level infestation of flower thrips and pod borer. Other IPM packages evaluated might be profitable in that situation where severe infestation of flower thrips and pod borer occurs. 
Table 1. Efficacy of IPM package s on the incidence of flower infestation and thrips population in mungbean during Kharif-1, 2015

\begin{tabular}{|c|c|c|c|c|c|c|}
\hline \multirow[t]{2}{*}{$\begin{array}{l}\text { Treatments } \\
\text { (IPM package) }\end{array}$} & \multicolumn{2}{|c|}{$\begin{array}{c}\text { Mean no. of thrips } \\
\text { infested flowers } / 30 \\
\text { open flowers }\end{array}$} & \multirow{2}{*}{$\begin{array}{l}\text { Reduction of } \\
\text { flower infestation } \\
\text { after } 1 \text { day of } \\
\text { spray }(\%)\end{array}$} & \multicolumn{2}{|c|}{$\begin{array}{l}\text { Mean no. of thrips/ } \\
30 \text { open flowers }\end{array}$} & \multirow{2}{*}{$\begin{array}{l}\text { Reduction of } \\
\text { thrips population } \\
\text { after } 1 \text { day of } \\
\text { spray }(\%)\end{array}$} \\
\hline & $\begin{array}{l}\text { Before } \\
\text { spray }\end{array}$ & $\begin{array}{l}\text { After } \\
\text { 1day of } \\
\text { spray }\end{array}$ & & $\begin{array}{l}\text { Before } \\
\text { spray }\end{array}$ & $\begin{array}{c}\text { After } 1 \\
\text { day of } \\
\text { spray }\end{array}$ & \\
\hline $\begin{array}{l}\text { WST + Azadirachtin 1EC (Bio-neem } \\
\text { plus) @ } 1 \mathrm{ml} / 1+\text { Spinosad (Success } 2.5 \\
\text { SC) @ } 1.25 \mathrm{ml} / 1\end{array}$ & 17.75 & $17.25 \mathrm{a}$ & 2.82 & 29.50 & $27.75 \mathrm{a}$ & 5.93 \\
\hline $\begin{array}{l}\text { WST + Chlorfenapyr (Intrepid 10 SC) } \\
@ 1 \mathrm{ml} / 1+\text { Emamectin Benzoate } \\
\text { (Proclaim 5 SG) @ 1g/l }\end{array}$ & 16.25 & $4.75 \mathrm{~b}$ & 70.77 & 25.75 & $5.50 \mathrm{~b}$ & 78.64 \\
\hline $\begin{array}{l}\text { Farmers' practice: Three spraying of } \\
\text { Imidachloprid (Imitaf } 20 \mathrm{SL} \text { ) @ } 0.5 \mathrm{ml} / 1\end{array}$ & 15.50 & $5.00 \mathrm{~b}$ & 67.74 & 29.75 & $6.25 \mathrm{~b}$ & 78.99 \\
\hline Untreated control (Water spray only) & 16.00 & $15.50 \mathrm{a}$ & 3.13 & 27.25 & $24.50 \mathrm{a}$ & 10.09 \\
\hline F- test & 6.43 & 31.33 & & 0.73 & 19.56 & \\
\hline
\end{tabular}

Note: In a column, treatment means having the same letter(s) are not significantly different by DMRT at $5 \%$ level. 
Table 2. Efficacy of IPM packages on the incidence of flower infestation and thrips population in mungbean during Kharif-1, 2016

\begin{tabular}{|c|c|c|c|c|c|c|}
\hline \multirow[t]{2}{*}{$\begin{array}{l}\text { Treatments } \\
\text { (IPM package) }\end{array}$} & \multicolumn{2}{|c|}{$\begin{array}{l}\text { Mean no. of thrips } \\
\text { infested flowers } / 20 \\
\text { open flowers }\end{array}$} & \multirow[t]{2}{*}{$\begin{array}{l}\text { Reduction of flower } \\
\text { infestation after } 1 \\
\text { day of spray }(\%)\end{array}$} & \multicolumn{2}{|c|}{$\begin{array}{l}\text { Mean no. of thrips/ } \\
20 \text { open flowers }\end{array}$} & \multirow{2}{*}{$\begin{array}{c}\text { Reduction of } \\
\text { thrips } \\
\text { population after } \\
1 \text { day of spray } \\
\text { (\%) }\end{array}$} \\
\hline & $\begin{array}{l}\text { Before } \\
\text { spray }\end{array}$ & $\begin{array}{l}\text { After } \\
\text { 1day of } \\
\text { spray }\end{array}$ & & $\begin{array}{l}\text { Before } \\
\text { spray }\end{array}$ & $\begin{array}{l}\text { After } 1 \\
\text { day of } \\
\text { spray }\end{array}$ & \\
\hline $\begin{array}{l}\text { WST + azadirachtin 1EC (Bio-neem plus) } \\
@ 1 \mathrm{ml} / 1+\operatorname{spinosad} \text { (Success } 2.5 \mathrm{SC} \text { ) @ }\end{array}$ & $11.13 \mathrm{ab}$ & $7.63 \mathrm{~b}$ & 31.45 & $16.13 \mathrm{~b}$ & $11.00 \mathrm{~b}$ & 31.80 \\
\hline $\begin{array}{l}1.25 \mathrm{ml} / 1 \\
\mathrm{WST}+\text { chlorfenapyr (Intrepid 10 SC) @ } \\
1 \mathrm{ml} / 1+\text { emamectin benzoate (Proclaim } 5 \\
\mathrm{SG} \text { ) } 1 \mathrm{~g} / \mathrm{l}\end{array}$ & $11.13 \mathrm{ab}$ & $3.38 \mathrm{c}$ & 69.63 & $14.38 \mathrm{bc}$ & $3.88 \mathrm{c}$ & 73.02 \\
\hline $\begin{array}{l}\text { Farmer's practice: Three spraying of } \\
\text { imidacloprid (Imitaf } 20 \mathrm{SL} \text { ) @ } 0.5 \mathrm{ml} / 1\end{array}$ & $10.00 \mathrm{~b}$ & $3.75 \mathrm{c}$ & 62.50 & $12.75 \mathrm{c}$ & $4.00 \mathrm{c}$ & 68.63 \\
\hline Untreated control (Water spray only) & $13.00 \mathrm{a}$ & $11.63 \mathrm{a}$ & 10.54 & $19.25 \mathrm{a}$ & $18.50 \mathrm{a}$ & 3.90 \\
\hline F-test & 3.76 & 24.70 & & 9.15 & 49.01 & \\
\hline
\end{tabular}

Note: In a column, treatment means having the same letter(s) are not significantly different by DMRT at $5 \%$ level. 
Table 3. Efficacy of IPM packages on the incidence of pod infestation and yield of Mungbean during kharif-I, 2015 and 2016

\begin{tabular}{|c|c|c|c|c|c|c|c|c|}
\hline \multirow[t]{2}{*}{$\begin{array}{l}\text { Treatments } \\
\text { (IPM package) }\end{array}$} & \multicolumn{2}{|c|}{$\begin{array}{l}\text { Pod infestation by } \\
\text { pod borer }(\%)\end{array}$} & \multicolumn{2}{|c|}{$\begin{array}{l}\text { Pod infestation } \\
\text { reduction over } \\
\text { control }(\%) \\
\end{array}$} & \multicolumn{2}{|c|}{ Grain yield (kg/ha) } & \multicolumn{2}{|c|}{$\begin{array}{l}\text { Yield increase over } \\
\text { control }(\%)\end{array}$} \\
\hline & 2015 & 2016 & 2015 & 2016 & 2015 & 2016 & 2015 & 2016 \\
\hline $\begin{array}{l}\text { WST + azadirachtin (Bio-neem plus } \\
1 \mathrm{EC}) @ 1 \mathrm{ml} / 1+\text { spinosad (Success } \\
2.5 \mathrm{SC}) @ 1.25 \mathrm{ml} / 1\end{array}$ & $\begin{array}{l}5.25 \mathrm{c} \\
(2.28)\end{array}$ & $\begin{array}{l}2.13 \mathrm{c} \\
(1.45)\end{array}$ & 66.13 & 68.44 & $1326 \mathrm{~b}$ & $1498 \mathrm{a}$ & 7.63 & 7.31 \\
\hline $\begin{array}{l}\text { WST + chlorfenapyr (Intrepid } 10 \\
\text { SC) @ 1ml/1 + emamectin benzoate } \\
\text { (Proclaim 5 SG) @ 1g/l }\end{array}$ & $\begin{array}{l}9.00 \mathrm{~b} \\
(2.97)\end{array}$ & $\begin{array}{l}2.63 \mathrm{c} \\
(1.61)\end{array}$ & 41.94 & 61.04 & $1378 \mathrm{a}$ & 1536 a & 11.85 & 10.03 \\
\hline $\begin{array}{l}\text { Farmer's practice: Three spraying of } \\
\text { imidacloprid (Imitaf } 20 \mathrm{SL} \text { ) @ } \\
0.5 \mathrm{ml} / 1\end{array}$ & $\begin{array}{c}12.00 \mathrm{ab} \\
(3.45)\end{array}$ & $\begin{array}{l}5.13 \mathrm{~b} \\
(2.26)\end{array}$ & 22.58 & 24.00 & $1345 a b$ & $1485 \mathrm{a}$ & 9.17 & 6.38 \\
\hline Untreated control (Water spray only) & $\begin{array}{c}15.50 \mathrm{a} \\
(3.93)\end{array}$ & $\begin{array}{l}6.75 \mathrm{a} \\
(2.60)\end{array}$ & - & - & $1232 \mathrm{c}$ & $1396 \mathrm{~b}$ & - & - \\
\hline F-test & 20.18 & 28.46 & & & 31.45 & 21.28 & & \\
\hline
\end{tabular}

- Values in the parentheses are the square root transformed mean values

Note: In a column, treatment means having the same letter(s) are not significantly different by DMRT at $5 \%$ level. 
Table 4. Cost and return analysis of IPM packages against flower thrips and pod borers of mungbean during kharif-1, 2015 \& 2016

\begin{tabular}{|c|c|c|c|c|c|c|c|c|c|c|c|c|}
\hline \multirow[t]{2}{*}{$\begin{array}{l}\text { Treatments } \\
\text { (IPM packages) }\end{array}$} & \multicolumn{2}{|c|}{ Yield (kg/ha) } & \multicolumn{2}{|c|}{$\begin{array}{c}\text { Addl. yield } \\
\text { over control } \\
(\mathrm{kg} / \mathrm{ha})\end{array}$} & \multicolumn{2}{|c|}{$\begin{array}{l}\text { Addl. return } \\
\text { over control } \\
(\mathrm{Tk} / \mathrm{ha}) \\
\end{array}$} & \multicolumn{2}{|c|}{$\begin{array}{c}\text { Cost of } \\
\text { insecticide } \\
\text { appl. (Tk/ha) }\end{array}$} & \multicolumn{2}{|c|}{$\begin{array}{l}\text { Net return } \\
(\mathrm{Tk} / \mathrm{ha})\end{array}$} & \multicolumn{2}{|c|}{$\begin{array}{l}\text { Marginal benefit } \\
\text { cost ratio } \\
(\mathrm{MBCR}) \\
\end{array}$} \\
\hline & 2015 & 2016 & 2015 & 2016 & 2015 & 2016 & 2015 & 2016 & 2015 & 2016 & 2015 & 2016 \\
\hline $\begin{array}{l}\text { WST + azadirachtin 1EC (Bio-neem } \\
\text { plus) @ } 1 \mathrm{ml} / 1+\text { spinosad (Success } \\
2.5 \mathrm{SC}) @ 1.25 \mathrm{ml} / \mathrm{l}\end{array}$ & 1326 & 1498 & 94 & 102 & 4700 & 5100 & 7060 & 7060 & -2360 & -1960 & -0.33 & -0.28 \\
\hline $\begin{array}{l}\text { WST + chlorfenapyr (Intrepid } 10 \\
\text { SC) @ 1ml/1 + emamectin benzoate } \\
\text { (Proclaim 5 SG) @ } 1 \mathrm{~g} / 1\end{array}$ & 1378 & 1536 & 146 & 140 & 7300 & 7000 & 6800 & 6800 & 500 & 200 & 0.07 & 0.03 \\
\hline $\begin{array}{l}\text { Farmers' practice: Three spraying of } \\
\text { imidachloprid (Imitaf } 20 \mathrm{SL} \text { ) @ } \\
0.5 \mathrm{ml} /\end{array}$ & 1345 & 1485 & 113 & 89 & 5650 & 4450 & 3375 & 3375 & 2275 & 1075 & 0.67 & 0.32 \\
\hline Untreated control (Water spray only) & 1232 & 1396 & - & - & - & - & - & - & - & - & - & - \\
\hline
\end{tabular}

Addl. $=$ Additional, appl. $=$ application

For calculating income and benefit the following market prices were used: Mungbean $=$ Tk. 50/kg, White sticky trap $=$ Tk. 15/trap, 50 trap $/ \mathrm{ha}$, Bio-neem plus $1 \mathrm{EC}=$ Tk. 3000/litre, Success $2.5 \mathrm{SC}=$ Tk. 2600/litre, Intrepid $10 \mathrm{SC}=$ Tk. 2000/litre, Proclaim $5 \mathrm{SG}=\mathrm{Tk} .4500 / \mathrm{kg}$ and Imitaf 20 SL = Tk. 2100/litre. Labour wage for spraying insecticides $=$ Tk. 300/day/labourer ( 8 hours day). 


\section{REFERENCES}

Bakr, M.A. 1998. Disease and insect management of mungbean and blackgram. Resource manualLocation specific technologies for rice based cropping systems under irrigated conditions. Thana cereal technology transfer and identification project, Dhaka. pp.201-205.

Chhabra, K.S. and Kooner, B.S.. 1985. Loss of summer mungbean due to insect pests in Punjub. Indian J. Entomol. 47(1):103-105.

Lal, S.S. 1985. A review of insect pests of mungbean and their control on India. Trop. Pest Management 31(2): 105-114.

Hossain, M.A., Zaman, M.S. and Alam, M.J. 2011. Management of flower thrips and pod borers in mungbean, Vigna radiata L.). Bangladesh J. Life Sci. 23(2): 79-86.

Hossain, M.A. 2014. Development of IPM practices for the control of flower thrips and pod borers in mungbean (Vigna radiata L.). Bull. Inst. Trop. Agr., Kyushu Univ. 37: 85-92.

Hossain, M.M., Uddin, M.K., Sarkar, D. and Alam, S.N. 2015. Development of insecticide based management approach against thrips and iris yellow spot virus in onion. Annual Report 2014-2015. Entomology Division. Bangladesh Agricultural Research Institute, Gazipur. pp 166-173.

Hossain, M.A. 2015a. Development of insecticide-based management package against insect pests of mungbean (Vigna radiata L.). Bull. Inst. Trop. Agr., Kyushu Univ. 38: 55-63.

Hossain, M.A. 2015b. Efficacy of some insecticides against insect pests of mungbean (Vigna radiata L.). Bangladesh J. Agril. Res. 40(4): 657-667.

Poehlman, J.M. 1991. The Mungbean. Oxford and IBH Publ. Co. Pvt. Ltd., New Delhi, Bombay and Calcutta, 292 pp.

Rahman, M.M., Bakr, M.A., Mia, M.F., Idris, K.M., Gowda, C.L.L., Kumar, J., Dev, U.K., Malek, M.A. and Sobhan, A. 2000. Legumes in Bangladesh. In: Johansen, C., Duxbury, J.M., Virmani, S.M., Gowda, C.L.L., Pande, S. and Joshi, P.K. (eds.). Legumes in rice and wheat cropping systems of the Indo-Gangetic Plain - Constraints and opportunities. Patancheru 502 324, Andhra Pradesh, India: ICRISAT and Ithaca, New York, USA: Cornell University. 230 pp.

Sarkar, M.A., Dutta, N.K., Mahmudunnabi, M., Begum, K., Ferdous, A.K.M.R.H., Rahman, A.K.M..Z., Sarkar, D. and Alam, S.N. 2015. Evaluation of different management packages against flower thrips and pod borers of mungbean both in farmers field and on station condition. Annual Report 2014-2015, Entomology Division, Bangladesh Agricultural Research Institute, Joydebpur, Gazipur. pp. 10-16. 